\title{
Food Additives in Products for Children Marketed in Brazil
}

\author{
A. S. G. Lorenzoni ${ }^{1}$, F. A. Oliveira ${ }^{2, *}$, F. Clade ra-Olive ${ }^{1}{ }^{1}$ \\ ${ }^{1}$ Institute of Food Science and Technology, Federal University of Rio Grande do Sul State, Av. Bento Gonçalves, 9500, Zip Code \\ 91501-970, Porto Alegre, RS, Brazil \\ ${ }^{2}$ Federal Institute of Education, Science and Technology of Rio Grande do Sul State, Osório, RS, Brazil
}

\begin{abstract}
Studies show children suffer from adverse effects to food additives, in both acute and chronic forms. Children are among the biggest consumers of processed products and have more susceptibility to these adverse effects. In Brazil, there are few data about the exposure to food additives. Therefore, the objective of this article is to elaborate a database of food additives present in products for children. This database was built from August 2010 to October 2010 from the nutritional information on products for children, which could be found on the web site of a Brazilian supermarket. The information contained on product labels of all foods commercialized on the site were analysed, and those with some description or image directed to children, as well as products generally consumed by children, were organized in four categories (cereals and cereal products, dairy and meat products, candy and chocolate, beverages). The number of additives present in each product, the percentages of each class of additive present in the different food categories and the presence of artificial dyes in each category were presented in tables. Among the 5882 products commercialized on the web site, excluding alcoholic beverages, $506(8.60 \%)$ products were classified as children products, from which 468 products contained information on their ingredients (and additives) and 438 products contained at least one additive in their formulation. The most used additives were lecithin $(45.30 \%)$ and citric acid $(22.86 \%)$ and artificial dyes allura red $(9.83 \%)$, tartrazine $(6.84 \%)$, sunset yellow $(5.77 \%)$, brilliant blue $(5.77 \%)$. Future studies could be carried out to evaluate the amount used and the intake of these additives by Brazilian children.
\end{abstract}

Keywords Food Additives, Children, Database, Artificial Dyes

\section{Introduction}

The Codex Alimentarius defines a food additive as any substance not normally consumed as a food by itself and not normally used as a typical ingredient of the food, whether or not it has nutritive value. The term does not include "contaminants" or substances added to food for maintaining or improving nutritional qualities[1]. This definition is the same used in the Brazilian food legislation, which requires that manufacturers inform the presence of food additives, i.e., their full name or its International Numbering System (INS) - as well as their function on food labels. In case of flavourings, only their function needs to be informed[2].

According to the Joint Expert Committee for Food Additives (JECFA), the acceptable daily intake (ADI) is the amount of a food additive (expressed on a body weight basis), which can be ingested daily during an entire lifetime without appreciable health $\operatorname{risk}[3]$.

Several studies indicate adverse effects to food additives,

* Corresponding author:

fernanda.oliveira@osorio.i frs.edu.br (F. A. Oliveira)

Published online at http://journal.sapub.org/fph

Copyright (C) 2012 Scientific \& Academic Publishing. All Rights Reserved in both acute and chronic forms, such as toxic reactions in metabolism, triggering allergies[4-5], carcinogenicity in animals [6], probable carcinogenicity in humans [7-8] and behavioural changes [9-10]. Regarding such effects, those that are linked to children health stand out, because children are among the biggest consumers of processed products and, thus, have more susceptibility to these adverse effects. Considering aspects of child health, JECFA recommends that no additives be used in foods for children under one year. Despite this recommendation, there are several products on the market, such as yogurt, jellies, soft drinks, cookies, and candy, among others, which are consumed both by children and adults, and are not subject to that regulation, therefore making the child mo re vulnerable[11].

Brazilian law permits the use of certain additives in transition food for in fants and young children (such as soup, puree and juice): some acids, antioxidants, flavourings, emu ls ifiers, thickeners and acidity regulators [12].

Additionally, the food market is constantly changing, leading to a growing diversity of available foods, which makes mothers and children eager to use new products[13]. Furthermore, these adverse effects are related to the frequency of consumption by bodyweight. Since children have lower weight, this tolerance is also lower[11]. 
In Brazil, another factor which is important to note is the increasing consumption of processed foods and a decreasing consumption of homemade food[14], which makes the intake of additives higher.

Dietary assessment and evaluation in infancy and childhood is of nutritional importance, with specific interest in the prevention of chronic diseases in later life. Food databases are very important in this sense[13]. In order to evaluate the exposure to food additives and their potential risk, the first step is to obtain appropriate estimations for the presence and quantity of a given chemical additive in a food item and in the diet in general[15]. In Brazil, there are few data about the exposure to food additives.

This research was carried out to assess additives in food products for children marketed in Brazil and to built a database with the presence of food additives in these products, particularly the presence of artificial colouring.

\section{Materials and Methods}

A database was built from August 2010 to October 2010 from the nutritional information on products for children, which can be found on the web site of the biggest Brazilian supermarket.

The labels of all food products commercialized on the site were analysed, and those with some description or image directed to children, as well as products generally consumed by children, were organized in four main categories: 1) cereals and cereal products, 2) dairy and meat products, 3) candy and chocolate and 4) beverages.

The number of additives present in each type of food in each category, the percentages of each class of additive present in the different food categories and the presence of artificial dyes (percentage) in each category were presented in tables

It is important to note that ingredients added to improve nutritional value of foods (as vitamins and minerals) were not considered in this work, since they are not considered additives by the Brazilian law[2].

\section{Results and Discussion}

Food additives are a sensitive topic, especially in the diet of children. Therefore, the elaboration of a database with information on food additives in commercial products is very important[13]. In this work, the nutritional information in the labels of 5882 products commercialized on the web site of the biggest Brazilian supermarket (except for alcoholic beverages ) we re observed, fro $m$ which $506(8.60 \%)$ products were classified as targeted at children. Within them, 129 $(25.49 \%)$ products were classified as cereals and cereal products, $54(10.67 \%)$ as dairy and meat products, 249 $(49.21 \%)$ as candy and chocolate and $36(7.11 \%)$ as beverages. From the 506 products selected on the website of the supermarket, $38(7.51 \%)$ did not contain ingredient information on their labels, and therefore were not considered in this study.
Table 1 shows the number of different additives present in each category of food. $93.59 \%(n=438)$ of the products with ingredient information $(\mathrm{n}=468)$ contain at least one additive, and $4.27 \%(n=20)$ contain ten or more additives ( 12 of them belong to the category of candy and chocolate, 6 to the category of cereals and derivates, and 2 to the category of dairy and meat products).

It is important to mention that some of these products are developed specially to young children and babies. Among baby foods, 9 products contain one additive in their formulation (sodium citrate $(n=1)$, ascorbic acid $(n=2)$ and citric acid $(n=6))$. A mong milk powder, 19 products contain one additive, two products contain two additives and one product contains three additives. Among the ones which contain one additive, 14 contain only lecithin, two contain citric acid and one contains flavourings. Among the two brands of milk powder which contain two additives, one contains flavouring and lecith in and one contains lactic acid and lecithin, and the product that contains three additives also contains modified starch, lecithin and guar gum.

Within the category of cereals and cereal products, $51.94 \%(n=67)$ of the products contain up to two additives. The additives noted in this category are sodium bicarbonate $(\mathrm{n}=36 ; 27.91 \%)$, soybean lecithin $(\mathrm{n}=31 ; 24.03 \%)$, and caramel colour $(\mathrm{n}=24 ; 18.60 \%)$.

Within the category of dairy and meat products, $87.04 \%$ (n $=47$ ) contain up to five additives. A single milk beverage with colourful cereals contains more than 10 additives (12 additives, including five artificial dyes: tartrazine, sunset yellow, brilliant blue, erythrosine and allura red).

Within the category of candy and chocolate, $77.11 \%(\mathrm{n}=$ 192) of the products contain from two to six additives. Two brands of coloured gums contained 12 different additives, particularly eight and six different artificial dyes for each brand, respectively.

Within the category of beverages all products contain between two and nine additives.

Table 2 shows the patterns of food additives and the percentage of their use by food category. The most widely used additives are flavourings, which are present in $78.85 \%$ of the products. The Brazilian legislation does not require specifying the flavourings in the nutritional information. For this reason, it was not possible to identify which flavourings are present in these food items. Apart from the flavourings, the most commonly categories of additives used are emulsifiers and stabilizers and acids. They represent, respectively, $70.73 \%$ and $31.62 \%$ of the frequency of the overall presence of additives in these food items (Table 2).

Considering each additive individually, lecithin (E322) and citric acid (E330) were the most commonly recorded additives (results not shown). Lecithin was present in $45.30 \%$ of the products and was widely used in candy and chocolate ( $65.46 \%$ of use). Citric acid was present in $22.86 \%$ of the products and it was widely used in beverages $(86.11 \%)$. Although they are widely used, those additives do not represent a risk for children health[16-17]. 
Table 1. Number of additives present in each cat egory of food (products without information were not considered in the percentage)

\begin{tabular}{|c|c|c|c|c|c|c|c|c|c|c|c|c|c|c|c|}
\hline $\begin{array}{l}\text { Number of } \\
\text { Additives }\end{array}$ & 0 & 1 & 2 & 3 & 4 & 5 & 6 & 7 & 8 & 9 & 10 & 11 & 12 & 13 & $\begin{array}{l}\text { Witho } \\
\text { ut Info } \\
\end{array}$ \\
\hline \multicolumn{16}{|l|}{$\begin{array}{c}\text { Cereals and } \\
\text { Cereal Products (n } \\
=129) \\
\end{array}$} \\
\hline Bread $(\mathrm{n}=2)$ & & & 1 & & & 1 & & & & & & & & & \\
\hline Cakes $(\mathrm{n}=11)$ & & & & & 1 & & 1 & 3 & 2 & 2 & & 1 & & 1 & \\
\hline Biscuits $(\mathrm{n}=21)$ & & 2 & & 3 & 3 & 3 & 2 & & 1 & 5 & 2 & & & & \\
\hline $\begin{array}{c}\text { Noodles and pasta } \\
(\mathrm{n}=10)\end{array}$ & & & 3 & 1 & 2 & & 1 & 1 & & & 1 & & 1 & & \\
\hline $\begin{array}{c}\text { Oatmeal and } \\
\text { porridges }(\mathrm{n}=18)\end{array}$ & 5 & 7 & 5 & & 1 & & & & & & & & & & \\
\hline Baby foods $(\mathrm{n}=17)$ & 8 & 9 & & & & & & & & & & & & & \\
\hline $\begin{array}{c}\text { Savoury snacks }(\mathrm{n}= \\
28)\end{array}$ & 1 & 4 & 6 & 1 & 7 & 1 & 4 & 1 & & 3 & & & & & 3 \\
\hline $\begin{array}{c}\text { Breakfast cereals ( } \mathrm{n} \\
=22)\end{array}$ & 7 & 5 & 4 & 1 & 2 & 2 & 1 & & & & & & & & \\
\hline$\%$ & $\begin{array}{r}16.2 \\
8 \% \\
\end{array}$ & $\begin{array}{r}20.9 \\
3 \% \\
\end{array}$ & $\begin{array}{r}14.7 \\
3 \% \\
\end{array}$ & $\begin{array}{c}4.65 \\
\%\end{array}$ & $\begin{array}{c}12.4 \\
0 \% \\
\end{array}$ & $\begin{array}{c}5.43 \\
\% \\
\end{array}$ & $\begin{array}{c}6.98 \\
\% \\
\end{array}$ & $\begin{array}{c}3.88 \\
\%\end{array}$ & $\begin{array}{c}2.33 \\
\%\end{array}$ & $\begin{array}{c}7.75 \\
\%\end{array}$ & $\begin{array}{c}2.33 \\
\%\end{array}$ & $\begin{array}{c}0.78 \\
\%\end{array}$ & $\begin{array}{c}0.78 \\
\%\end{array}$ & $\begin{array}{c}0.78 \\
\%\end{array}$ & \\
\hline \multicolumn{16}{|l|}{$\begin{array}{c}\text { Dairy and Meat } \\
\text { Products }(\mathrm{n}=54) \\
\end{array}$} \\
\hline $\begin{array}{c}\text { Yogurt and milk } \\
\text { beverages }(n=14)\end{array}$ & & & 2 & 2 & 2 & 2 & & 1 & 3 & & 1 & & 1 & & 4 \\
\hline Special milk $(\mathrm{n}=9)$ & & 4 & 3 & 2 & & & & & & & & & & & \\
\hline $\begin{array}{l}\text { Milk powder }(\mathrm{n}= \\
26)\end{array}$ & 4 & 19 & 2 & 1 & & & & & & & & & & & \\
\hline $\begin{array}{l}\text { Meat products }(\mathrm{n}= \\
5)\end{array}$ & & & 1 & 1 & 1 & 1 & & 1 & & & & & & & \\
\hline$\%$ & $\begin{array}{c}7.41 \\
\%\end{array}$ & $\begin{array}{r}42.5 \\
9 \% \\
\end{array}$ & $\begin{array}{c}14.8 \\
1 \% \\
\end{array}$ & $\begin{array}{c}11.1 \\
1 \% \\
\end{array}$ & $\begin{array}{c}5.56 \\
\%\end{array}$ & $\begin{array}{c}5.56 \\
\%\end{array}$ & $\begin{array}{c}0.00 \\
\%\end{array}$ & $\begin{array}{c}3.70 \\
\%\end{array}$ & $\begin{array}{c}5.56 \\
\%\end{array}$ & $\begin{array}{c}0.00 \\
\%\end{array}$ & $\begin{array}{c}1.85 \\
\%\end{array}$ & $\begin{array}{c}0.00 \\
\%\end{array}$ & $\begin{array}{c}1.85 \\
\%\end{array}$ & $\begin{array}{c}0.00 \\
\%\end{array}$ & \\
\hline \multicolumn{16}{|l|}{$\begin{array}{c}\text { Candy and } \\
\text { chocolate }(n=249) \\
\end{array}$} \\
\hline Gums $(n=62)$ & 3 & 1 & 3 & 5 & 4 & 8 & 9 & 12 & 10 & 2 & 3 & 0 & 2 & & 4 \\
\hline $\begin{array}{c}\text { Chocolate } \\
\text { confectionery }(\mathrm{n}= \\
44) \\
\end{array}$ & & 1 & 2 & 13 & 26 & 1 & 1 & & & & & & & & 10 \\
\hline Jellies $(n=18)$ & & & & 1 & 2 & 2 & 4 & & 1 & 6 & 2 & & & & 8 \\
\hline Candy $(\mathrm{n}=37)$ & 2 & & 9 & 12 & 3 & 2 & 1 & 2 & & 1 & 5 & & & & 4 \\
\hline $\begin{array}{c}\text { Chocolate bars }(\mathrm{n}= \\
69)\end{array}$ & & 2 & 8 & 52 & 4 & 2 & 1 & & & & & & & & 5 \\
\hline $\begin{array}{c}\text { Chocolate and other } \\
\text { powder beverages } \\
(\mathrm{n}=19)\end{array}$ & & 2 & 7 & 6 & 2 & 1 & 1 & & & & & & & & \\
\hline$\%$ & $\begin{array}{c}2.01 \\
\% \\
\end{array}$ & $\begin{array}{c}2.41 \\
\% \\
\end{array}$ & $\begin{array}{r}11.6 \\
5 \% \\
\end{array}$ & $\begin{array}{r}35.7 \\
4 \% \\
\end{array}$ & $\begin{array}{r}16.4 \\
7 \% \\
\end{array}$ & $\begin{array}{c}6.43 \\
\% \\
\end{array}$ & $\begin{array}{c}6.83 \\
\% \\
\end{array}$ & $\begin{array}{c}5.62 \\
\% \\
\end{array}$ & $\begin{array}{c}4.42 \\
\% \\
\end{array}$ & $\begin{array}{c}3.61 \\
\% \\
\end{array}$ & $\begin{array}{c}.02 \\
\% \\
\end{array}$ & $\begin{array}{c}0.00 \\
\% \\
\end{array}$ & $\begin{array}{c}0.80 \\
\% \\
\end{array}$ & $\begin{array}{c}0.00 \\
\% \\
\end{array}$ & \\
\hline \multicolumn{16}{|l|}{ Be ve rages $(n=36)$} \\
\hline Sodas $(\mathrm{n}=24)$ & & & 1 & 2 & 6 & 6 & 3 & 5 & & 1 & & & & & \\
\hline $\begin{array}{c}\text { Other beverages ( } \mathrm{n} \\
=12)\end{array}$ & & & 2 & 1 & & 1 & 2 & 3 & 3 & & & & & & \\
\hline$\%$ & & & $8.3 \%$ & $8.3 \%$ & $\begin{array}{c}16.7 \\
\% \\
\end{array}$ & $\begin{array}{c}19.4 \\
\%\end{array}$ & $\begin{array}{c}13.9 \\
\%\end{array}$ & $\begin{array}{c}22.2 \\
\% \\
\end{array}$ & $\begin{array}{c}8.3 \\
\% \\
\end{array}$ & $\begin{array}{c}2.8 \\
\% \\
\end{array}$ & & & & & \\
\hline Total & 30 & 56 & 59 & 104 & 66 & 33 & 31 & 29 & 20 & 20 & 14 & 1 & 4 & 1 & 38 \\
\hline$\%$ & $\begin{array}{c}6.41 \\
\%\end{array}$ & $\begin{array}{r}11.9 \\
7 \% \\
\end{array}$ & $\begin{array}{c}12.6 \\
1 \% \\
\end{array}$ & $\begin{array}{r}22.2 \\
2 \% \\
\end{array}$ & $\begin{array}{c}14.1 \\
0 \% \\
\end{array}$ & $\begin{array}{c}7.05 \\
\% \\
\end{array}$ & $\begin{array}{c}6.62 \\
\% \\
\end{array}$ & $\begin{array}{c}6.20 \\
\% \\
\end{array}$ & $\begin{array}{c}4.27 \\
\%\end{array}$ & $\begin{array}{c}4.27 \\
\%\end{array}$ & $\begin{array}{c}2.99 \\
\%\end{array}$ & $\begin{array}{c}0.21 \\
\%\end{array}$ & $\begin{array}{c}0.85 \\
\% \\
\end{array}$ & $\begin{array}{c}0.21 \\
\%\end{array}$ & \\
\hline
\end{tabular}


Table 2. Patterns of food additives and percentage of their usage in categories of food

\begin{tabular}{|c|c|c|c|c|c|}
\hline Additive & $\begin{array}{c}\text { Cereals and } \\
\text { Cereal Products } \\
(\%) \\
\end{array}$ & $\begin{array}{c}\text { Dairy and Meat } \\
\text { Products } \\
(\%) \\
\end{array}$ & $\begin{array}{l}\text { Candy and } \\
\text { chocolate } \\
(\%)\end{array}$ & $\begin{array}{c}\text { Beverages } \\
(\%)\end{array}$ & $\begin{array}{c}\text { Total } \\
(\%)\end{array}$ \\
\hline Flavourings & 62.79 & 37.85 & 94.42 & 88.89 & 78.85 \\
\hline Emulsifiers and Stabilizers & 41.09 & 73.56 & 89.24 & 44.44 & 70.73 \\
\hline Acids & 20.93 & 29.85 & 28.69 & 94.44 & 31.62 \\
\hline Natural colouring & 37.21 & 11.85 & 8.37 & 63.89 & 20.94 \\
\hline Artificial colouring & 10.08 & 14.00 & 28.29 & 19.44 & 20.94 \\
\hline Chemical Leavening Agents & 29.46 & & 14.34 & & 15.81 \\
\hline Preservatives & 10.08 & 22.00 & & 75.00 & 11.11 \\
\hline Anti-caking agents & 18.60 & 2.00 & & & 5.34 \\
\hline Flavour enhancers & 16.28 & 5.56 & & & 5.13 \\
\hline Humectants & 6.98 & & 4.38 & & 4.27 \\
\hline Sweet eners & & 4.00 & 3.59 & 19.44 & 3.85 \\
\hline Gelling agents & & & 6.37 & & 3.42 \\
\hline Antioxidants & 0.78 & 7.56 & & 19.44 & 2.56 \\
\hline Thickeners & 0.78 & 1.85 & 1.20 & 5.56 & 1.50 \\
\hline Glazing agents & & 2.00 & & & 0.21 \\
\hline
\end{tabular}

Table 3. Artificial colouring present in each category of food

\begin{tabular}{c|c|c|c|c|c}
\hline Artificial Dye & $\begin{array}{c}\text { Cereals and cereal } \\
\text { products }\end{array}$ & $\begin{array}{c}\text { Dairy and Meat } \\
\text { products }\end{array}$ & Candy and chocolate & Be ve rages & Total \\
\hline Allura Red AC (E129) & $5.43 \%$ & $5.56 \%$ & $14.46 \%$ & $10.84 \%$ & $5.56 \%$ \\
\hline Tartrazine (E102) & $2.33 \%$ & & $7.23 \%$ & $11.11 \%$ & $5.77 \%$ \\
\hline Sunset Yellow FCF (E1 10) & $3.10 \%$ & $1.85 \%$ & $6.02 \%$ & $11.11 \%$ & $5.77 \%$ \\
\hline Brilliant Blue FCF (E133) & $3.10 \%$ & $7.41 \%$ & $6.43 \%$ & & $4.27 \%$ \\
\hline Ponceau 4R (E124) & $0.78 \%$ & $5.56 \%$ & $4.42 \%$ & $8.33 \%$ & $3.42 \%$ \\
\hline Amaranth (E123) & & $3.70 \%$ & $4.42 \%$ & & $2.35 \%$ \\
\hline Azorubine (E122) & & & $3.61 \%$ & & $2.14 \%$ \\
\hline Indigo carmine (E132) & $0.78 \%$ & & $2.01 \%$ & & $1.28 \%$ \\
\hline Erythrosine (E127) & & & & & \\
\hline
\end{tabular}

In Table 2 it is possible to see that both artificial and natural dyes are present in $20.94 \%$ of all the products. It is also possible to see that natural colourings are most used in beverages and cereals and cereal products. Moreover, the artificial dyes are mostly present in the categories of candy and chocolate and also in beverages.

Many products which had a description or an image directed to children, in addition to candy, cereal and soft drinks contain artificial colouring in their formulation. Their presence in each food category was evaluated as shown in table 3.

The artificial dyes most frequently found in these foods, according to the information on their labels, were allure red $(9.83 \%)$, tartrazine $(6.84 \%)$, sunset yellow $(5.77 \%)$, brilliant blue $(5.77 \%)$ and ponceau (4.27\%). The intake of artificial dyes is the focus of many recent studies[18-21].

[22] carried out a study to investigate the types and levels of colour additives added to various foods in the city of Hyderabad and surrounding rural areas in India. A mong the 700 food items collected and analysed from urban areas and 300 from rural areas, respectively $93 \%$ and $95 \%$ were found to contain permitted colour additives. In this country, an assessment of the exposure to synthetic food dyes was carried out among 1-5 and 6-18-year-old individuals using the food frequency method. The intakes of some individuals exceeded the acceptable daily intake (ADI) for tartrazine, sunset yellow and erythrosine[21].

[23] carried out a survey on food consumption in Kuwait to identify the types and quantities of coloured food items which are most commonly consumed by children. Among the 344 food items analysed, 308 samples, i.e. about $90 \%$, contained artificial colour additives that are permitted in foods by the Kuwaiti authorities. Tartrazine (49.5\%) and sunset yellow (45.3\%) were the most commonly used permitted colour additives, followed by allura red (39.7\%), brilliant blue (39.7\%) and carmo isine $(24.8 \%)$. In this country,[20] assessed the intake of artificial food dyes additives by 5-14-year-old children. A 24-h dietary recall was carried out twice on 3141 children, male and female, from 58 schools. The results showed that out of nine permitted dyes, four exceeded their ADI for these people: tartrazine, sunset yellow, carmo is ine and allu ra red. 
In Brazil,[23] stated that children of different ages consumed variable amounts of artificial colouring through widespread industrialized products (in many cases these products were introduced before 1 year of age). The study took place in a Hospital in Rio de Janeiro with 150 children and shows that the great majority surpassed the daily ingestion permitted for amaranth and $20 \%$ of the children surpassed the daily ingestion for sunset yellow.

\section{Conclusions}

This database shows that, despite being classified as children products, $93.59 \%$ of the 468 products contain at least one additive in their formulation. It was also found that $45.30 \%$ of the children products contain lecithin and $22.86 \%$ contain citric acid, the most used additives. Although they are widely used, those additives do not represent a risk for children health. Detailed data about artificial colouring is presented: the most widely used dyes were allura red $(9.83 \%)$, tartrazine $(6.84 \%)$, suns et yellow and brilliant blue $(5.77 \%)$. Artificial dyes are more frequent in the category of candy and chocolate (about $30 \%$ of these products contain at least one artificial dye). Future studies that assess the amount of additives used in foods and estimated dietary intake by Brazilian children could be carried out, since children are among the biggest consumers of processed products and have more susceptibility to the adverse effects caused by food additives.

\section{REFERENCES}

[1] Codex Alimentarius Commission. Procedural Manual. 20th ed. Rome (Italy): Food and Agriculture Organization of the United Nations, 2011.

[2] Brazil. Resolução RDC No 259/2002. Brasília DF (Brazil): Diário Oficial da união; [cited 2011 Jun 30]. Available from: http://www.anvisa.gov.br/legis/resol/2002/259_02rdc.htm.

[3] World Health Organization (WHO). Principles for the Safety Assessment of Food Additives and Contaminants in Food. (1987). Geneva, (Switzerland): World Health Orgnization;[cited 2011 Jun 30]. Available from: http ://www.inchem.org/documents/ehc/ehc/ehc70.htm.

[4] Worm, M., Vieth, W., Ehleres, I., Sterry, W., \& Zuberbier, T. Increased leukotriene production by food additives in patients with atopic dermatitis and proven food intolerance. Clinical and Experimental Allergy, 31(2), 265-273, 2001.

[5] Sauvage, C. Controverse l'hypersensibilité aux additifs alimentaires est une réalité clinique: pour. Revue française d'allergo logie, 50, 288-291, 2010.

[6] Shimada, C., Kano, K., Sasaki, Y.F., Sato, I., \& Tsudua, S. Differential colon DNA damage induced by azo food additives between rats and mice. The journal of toxicological sciences, 35(4), 547-554, 2010.

[7] Sugimura, T. Mutagens, carcinogens, and tumor promoters in our daily food. Cancer, 49(10), 1970-1984, 1982.
[8] Knekt, P., Jarvinen, R., Dich, J., \& Hakulinen, T. Risk of colorectal and other gastro-intestinal cancers after exposure to nitrate, nitrite and $\mathrm{N}$-nitroso compounds: A follow-up study. International Journal of Cancer, 80(6), 852-856, 1999.

[9] Bateman, B., Warner, J.O., Hutchinson, E., Dean, T., Rowlandson, P., Gant, C., Grundy, J., Fitzgerald, C., \& Stevenson, J. The effects of a double blind, placebo controlled, artificial food colourings and benzoate preservative challenge on hyperactivity in a general population sample of preschool children. Archives of Disease in Childhood, 89(6), 506-511, 2004.

[10] McCann, D., Barrett. A., Cooper, A., Crumpler, D., Dalen, L., Grimshaw, K., Kitchin, E., Lok, K., Porteous, L., Prince, E., et al. Food additives and hyperactive behaviour in 3-year-old and 8/9-year-old children in the community: a randomised, double-blinded, placebo-controlled trial. Lancet, 370, 1560-67, 2007.

[11] Polônio, M.L.T., \& Peres, F. Food additive intake and health effects: public health challenges in Brazil. Cadernos de Saúde Pública, 25(8), 1653-1666, 2009.

[12] Brazil. Portaria $\mathrm{N}^{\circ}$ 35/1998. Brasília DF (Brazil): Diário Oficial da união;[cited 2011 Jun 30]. Available from: http://www.anvisa.gov.br/legis/portarias/35_98.htm.

[13] Sichert-Hellert, W., Kersting, M., Chahda, C., Schafer, R., \& Kroke, A. German food composition database for dietary evaluations in children and adolescents. Journal of Food Composition and Analysis, 20, 63 - 70, 2007.

[14] IBGE - Brazilian Institute of Geography and Statistics. Family Budget Survey 2008-2009. 1st ed. Rio de Janeiro (RJ) Brazil, 2010.

[15] Kroes, R., Muller, D., Lambe, J., Lowik, M.R., van Klaveren, J., Kleiner, J., Massey, R., Mayer, S., Urieta, I., Verger, P., \& Visconti, A. Assessment of intake from the diet. Food and Chemical Toxicology, 40(3), 327-385, 2002.

[16] JECFA - Joint Expert Committee on Food Additives. Summary of Evaluations Performed by the Joint FAO/WHO Expert Committee on Food Additives.[cited 2011 jun 30]. Available from: http://www.inchem.org/documents/jecfa/jec eval/jec_436.htm. 2001.

[17] JECFA - Joint Expert Committee on Food Additives. Summary of Evaluations Performed by the Joint FAO/WHO Expert Committee on Food Additives.[cited 2011 jun 30]. Available from: http://www.inchem.org/documents/jecfa/jec eval/jec_1261.htm. 2004.

[18] Lok, K.Y., Chung, W., Benzie, I.F.F., \& Woo, J. Colour additives in snack foods consumed by primary school children in Hong Kong. Food Additives and Contaminants Part B, 3(3), 148-155, 2010.

[19] Schumann, S.P.A., Polônio, M.L.T., \& Gonçalves, E.C.B.A. Avaliação do consumo de corantes artificiais por lactentes, escolares e pré-escolares. Ciên cia e Tecnologia de Alimentos, 28(3), 534-539, 2008.

[20] Husain, A., Sawaya, W., Al-Omair, A., Al-Zenki, S., \& Al-Amiri, H. Estimates of dietary exposure of children to artificial food colours in Kuwait. Food Additives and Contaminants, 23(3), 245-51, 2006.

[21] Rao, P., Bhat, R.V., \& Sudershan, R.V. Exposure assessment to synthetic food colors of a selected population in Hy derabad, 
India. Food Additives and Contaminants, 21(5), 415-421, 2004.

[22] Rao P., \& Bhat, R.V. A comparative study on the synthetic food colours usage in foods procured from urban and rural areas of Hyderabad. Nutrition \& Food Science, 33(5), 230 -
234, 2003.

[23] Sawaya, W., Husain, A., Al-Otaibi, J., Al-Foudari, M., \& Hajji, A. Colour additive levels in foodstuffs commonly consujme by children in Kuwait. Food Control, 19, 98-105, 2008. 